\title{
An Effective Wood DNA Extraction Protocol for Three Economic Important Timber Species of India
}

\author{
Tanzeem Fatima1, Ashutosh Srivastava ${ }^{*}$, Vageeshbabu S. Hanur ${ }^{2}$, M. Srinivasa Rao ${ }^{3}$ \\ ${ }^{1}$ Tree Improvement and Genetics Division, Institute of Wood Science and Technology, Bangalore, India \\ ${ }^{2}$ Division of Biotechnology, Indian Institute of Horticultural Research, Bangalore, India \\ ${ }^{3}$ Policy Research Policy and Management Institute of Wood Science and Technology, Bangalore, India \\ Email: *ashutosh@icfre.org
}

How to cite this paper: Fatima, T., Srivastava, A., Hanur, V.S. and Srinivasa Rao, M. (2018) An Effective Wood DNA Extraction Protocol for Three Economic Important Timber Species of India. American Journal of Plant Sciences, 9, 139-149.

https://doi.org/10.4236/ajps.2018.92012

Received: October 24, 2017

Accepted: January 16, 2018

Published: January 19, 2018

Copyright $\odot 2018$ by authors and Scientific Research Publishing Inc. This work is licensed under the Creative Commons Attribution International License (CC BY 4.0).

http://creativecommons.org/licenses/by/4.0/

\begin{abstract}
Extraction of DNA from fresh tissues is routine in studies of tropical forest species, but DNA extraction from wood is considered as difficult due to its highly degraded nature and adequate quality of genomic DNA extraction is essential for molecular studies. Very few studies have validated the potential for isolating DNA from dried wood (Heartwood and Sapwood). Wood genomic DNA extraction is difficult from mature timber (Teak (Tectona grandis f; verbanaceae), Black Rosewood (Dalbergia latifolia f; Fabaceae) Ben Teak (Lagerstroemia lanceolata f; Lytheraceae) tissues due to presence of high quantity of secondary metabolites polyphenols, tannins and terpenoids and protein inhibitors. Mostly in laboratories DNA extraction kits are available but by using kits, DNA yield is very low and it is quite expensive too. We have standardized and validated the DNA extraction through manual protocol which is applicable for Bark, Sapwood and Heartwood samples of tree species which contains huge amount of inflexible tissues and fibers. The quality of the DNA was tested by spectrophotometer, gel electrophoresis and PCR (ISSR and SSR) amplification. An avrage DNA yield for heartwood ranges from $0.186-0.166 \mu \mathrm{g} / \mu \mathrm{L}$ and sapwood was ranges from $0.26-0.244 \mu \mathrm{g} / \mu \mathrm{L}$. Modification of CTAB method was by addition of polyvinylpyrrolidone (PVP) appx $0.25 \%$, variation in Rnase concentration, proteinase treatment with different concentration and incubation time. In order to evaluate the standardized wood genomic DNA extraction protocol, we compared it with the mature leaf and core samples (heartwood and sapwood) of the same timber species. The outcome was also quantified and proved by means of polymerase chain reaction analysis by using ISSR and SSR microsatellite markers conducted with isolated pure DNAs. This modified protocol made increased yield and purity of wood total genomic DNA and facilitate the important application of foren-
\end{abstract}


sic timber species effort.

\section{Keywords}

Wood Genomic DNA, Plant DNA Kits, Timber, ISSR and SSR Markers

\section{Introduction}

Preservation of endangered species is an indispensible part of accomplishment the objective of the Convention on Biological Diversity 2020 on cultivating the prominence of global biodiversity [1]. The first critical phase in protecting and managing threatened species is correct identification and delimitation of the target species [2]. Identification of plant species traditionally relies on morphological characters of especially leaf, flowers and fruits, which for trees can be time consuming to access and only present during parts of the year. Accurate identification in species-rich or taxonomically complex groups also typically requires genomic DNA that is not always available, especially in tropical forest samples [3] [4]. Teak (Tectona grandis f; verbanaceae), Black Rosewood (Dalbergia latifolia f; Fabaceae) Ben Teak (Lagerstroemia lanceolata f; Lytheraceae) are incredibly significant economic timber species in tropical countries chiefly in India, Indonesia, Myanmar and Burma. These three genuses contain many valuable timber species threatened by illegal logging and deforestation, but knowledge on distribution and threats is often limited and accurate species identification difficult. Illegal logging and associated trade are the cause of many economic and ecological problems both in timber producer and timber consumer countries [5]. Although many legal instruments have been established to combat illegal logging and trade of illegally sourced timber, practical controls mechanisms to identify the tree species and geographic origin of wood and wood products are still lacking [6] [7]. The action of illegal logging crimes is hampered by a lack of available forensic timber identification tools and time of harvest for both screening of suspect material and definitive identification of illegally sourced wood, which were scam by forest department. Processed timber products such as decking, flooring and furniture are subjected to drying, engineering and treatment processes that degrade the DNA present in the wood, just as in ancient samples [8]. Extraction of whole genomic DNA from fresh tissues is routine in studies of tropical forest species [9] [10]. DNA extraction from wood (Sapwood and heartwood) is quite difficult due to presence of higher quantity of secondary metabolites phenolic and lignin compounds and the concentration of leaf DNA is higher than wood DNA [11] [12]. There are number of protocols for DNA extraction from various plant and animal species and tissues published, but these protocols are the best for leaf and soft tissues, while mature tree samples (core tissues) often narrows down the scope of DNA extraction [13]. Genotypes the tracing of timber origin, and species can be identified based on an investigation of wood if suitable DNA content and high amount of pure DNA is 
available [14]. The aims for this study were to optimize the total genomic DNA extraction protocol by means of the standardized the modified CTAB wood (heartwood and sapwood) DNA extraction protocol [15] [16] and the comparison between the modified CTAB protocol, CTAB protocol and Plant DNA extraction kits (Nucleopore) protocols. This modified protocol made the intact wood DNA isolation that facilitates the important forensic timber species effort.

\section{Materials and Methods}

\subsection{Sampling}

Collection of leaves and core samples from naturally grown populations of southern regions of Karnataka such as Virnoli and Barchi range, Jangganmatti, (N15¹3'49.4" E074³8'27.9"), Dharwad district (Haliyal region), and Hassan (Alur Taluk) Figure 1(a) were carried out.

Mature and dried leaves were collected by climbing of the tree with the help of forest guards Figurre 1(b) and core samples were taken by penetrating increment borer in the trunk near breast height and free of limbs, knobs, or other growths of the tree Figurre 1(c) and rotated manually from the selected samples and after collection of core Figurre 1(d). Sealed the holes with small dry twigs in the trunk and closed it with paraffin wax to reduce the fungal infections or other injuries to the selected trees.

\subsection{Storage}

Leaf and core samples were put into plastic cover and immediately placed into an ice storage box. After arrival to the laboratory the wood samples that had

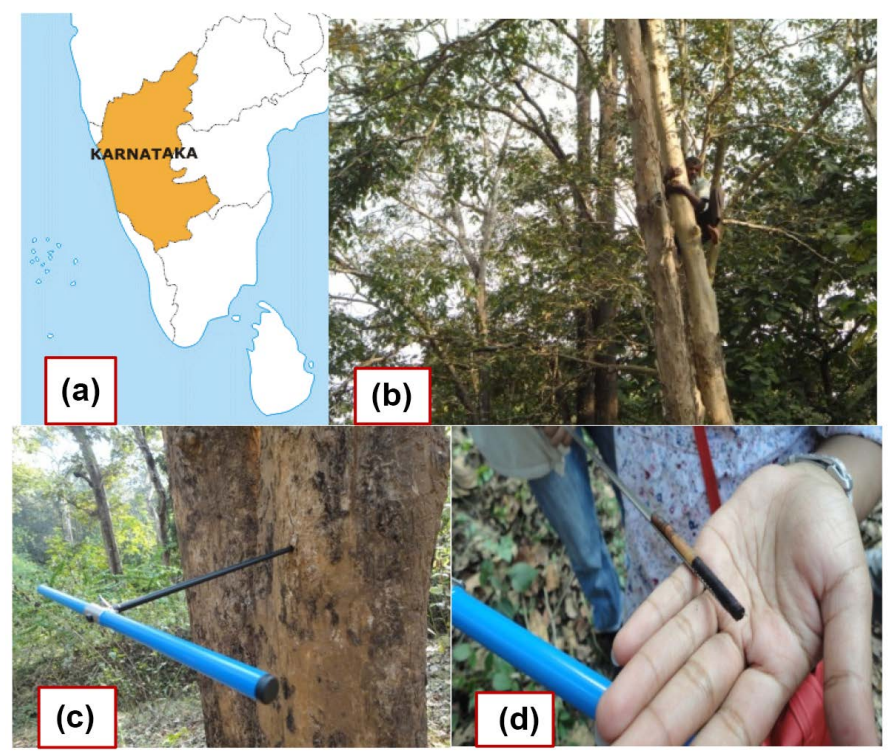

Figure 1. (a) Sample collection of leaves and core from virnoli Barchi range Dharwad district; (b) Collection of leaf samples; (c) Increment borer; (d) core samples of important (D. latifolia, L.lanceolata and $T$. grandis) timbers. 
been placed in the ice storage box were transferred at once to a $-20^{\circ} \mathrm{C}$ cryogenic freezer(Siemen pvt. ltd.) to maintain their freshness.

\subsection{Sample Preparation}

Before DNA extraction, core samples were cleaned and washed with distilled water and kept it in a fresh autoclaved glass bottles with distilled water for about $72-96 \mathrm{~h}$ and repeatedly changed the water at every $12 \mathrm{~h}$ to avoid the fungal or any other contaminations. Samples were cut into two Sections 1. Sapwood 2. Heartwood, cut the samples separately of an approx. $3-5 \mu \mathrm{M}$ thickness was prepared from each samples using paper cutter or sliding microtome to produce small chips of wood samples. Kept the chipped slices for drying $5-10$ min before imperilling to for $\mathrm{CTAB}$ based protocols for genomic DNA extraction which comprised of CTAB method [17], DNAsure plant mini kit (Nucleopore) [18], and CTAB method (protocol 3) developed at IWST laboratory. Protocol 1 are executed earlier while the protocol 2 are kit manufacturer based and all are a routine based protocol published in number of papers so here only the modified standardised developed i.e., protocol 3 (modified CTAB) has been described below.

\subsection{Protocol 3: CTAB Extraction Buffer}

3.5\% (w/v) CTAB, $0.25 \%$ (w/v) PVPP, $1.4 \mathrm{mM} \mathrm{NaCl}, 20$ mMEDTA, $100 \mathrm{mM}$ Tris-HCl (pH 8.0), $2.5 \%$ (v/v) $\beta$-mercaptoethanol.

\subsection{Method}

Around $500 \mathrm{mg}$. samples (sapwood, heartwood and leaf separately)were taken into chilled autoclaved mortar pestle and added $250 \mathrm{mg}$. PVPP then rapidly ground it into a fine powder using liquid nitrogen. After grinding added pre-wormed at $65^{\circ} \mathrm{C}$ extraction buffer and vigorously shaken the tubes in vortex for few seconds and retained it at $65^{\circ} \mathrm{C}$ pre-heated water bath for $2^{1 / 2} \mathrm{~h}$ with periodic shuddering. Taken away the reaction tubes from water bath and retained it at room temperature to cool it for $30 \mathrm{~min}$. Added $5 \mathrm{~mL}$ P:C:I (Phenol:chloroform:Isoamylalcohol 25:24:1) in each tube and moderately shaken it for $5 \mathrm{mi}$ nutes. Centrifuged the tubes at $10,000 \mathrm{rpm}$ for $10 \mathrm{~min}$ at $4^{\circ} \mathrm{C}$ temperature. Allocated the transparent color supernatant into fresh autoclaved tubes and castoff the debris content and added $6 \mathrm{ml}$. C:I (chloroform:Isoamylalcohol 24:1). Agitated the tubes gently without affecting the DNA in solution for $10 \mathrm{~min}$ to remove the protein and carbohydrate contaminations. Repeat the similar step twicedue to presence of heavy amount of protein and lignin content to get clear supernatant. In the next step added $30 \mu \mathrm{L}$ RNase (sigma Aldrich) $(20 \mathrm{mg} / \mathrm{mL})$ in each tube and gently mixed it with the help of micropipette. Allowed it into dry bath (Bio-Rad pvt. Itd.) at $37^{\circ} \mathrm{C}$ for $40 \mathrm{~min}$. After RNase treatment, added $30 \mu \mathrm{L}$ proteinase K (Sigma Aldrich) $(20 \mathrm{mg} / \mathrm{mL})$ [19] in respective tubes with gently mixing two three times and retained it in dry bath at $37^{\circ} \mathrm{C}$ to precipitate the 
protein contaminations for $2 \mathrm{~h}$. Carryout the samples from dry bath and washed it another time with C:I and spin the samples at $12,000 \mathrm{rpm}$ for $12 \mathrm{~min}$ at $4^{\circ} \mathrm{C}$. Transferred the $4 \mathrm{~mL}$ supernatant in new $15 \mathrm{~mL}$ reaction tubes and added $1 \mathrm{~mL}$ $5 \mathrm{M} \mathrm{NaCl}, 1 \mathrm{M}$ Sodium acetate $1 \mathrm{~mL}$ and equal volume of chilled isopropanol in each samples. Allowed it to overnight incubation at $-20^{\circ} \mathrm{C}$ for overnight and next day centrifuged it at $12,000 \mathrm{rpm}$ for $15 \mathrm{~min}$ at $4^{\circ} \mathrm{C}$. Discarded the supernatant and the retained transparent pellet transferred into anew autoclaved $1.5 \mathrm{~mL}$ reaction tubes. Washed the pellet twice with $1 \mathrm{~mL} 70 \%$ ethanol using short spin in mini centrifuge at $10,000 \mathrm{rpm}$ for $5 \mathrm{~min}$ at to remove any remaining salts in tubes. Afterwards washing the pellet was allowed to dry. Re-suspended in 30 - 50 $\mu \mathrm{L}$ TE (Tris-EDTA) ( $\mathrm{pH}$ 8.0) buffer. Dissolved it appropriately and kept the DNA containing tubes at $4^{\circ} \mathrm{C}$ for further analysis.

\subsection{DNA Quantification}

The yield of extracted DNA was quantified by nanodrop at 260/280 nm wavelength [20]. The purity of DNA was checked by running the samples on $0.8 \%$ agarose gel in $1 \mathrm{X}$ TAE buffer $(8.0 \mathrm{pH})$ stain containing $4 \mu \mathrm{L}$ of $0.3 \%$ Ethidium Bromide and visualized on UV transilluminator gel doc (Syngene version 7.0) to get the DNA bands.

\subsection{DNA analysis through ISSR and Universal SSR (RbcL \& TrnH) Markers}

Ten ISSR primers were screened for analysis [20] [21] out of those four primers was amplified and showing high polymorphism in all three species. UBC834 (AG) $)_{8}$ YT, UBC874 (CCT) ${ }_{4}, \mathrm{UBC} 848(\mathrm{CA})_{8} \mathrm{RG}, \mathrm{UBC} 857$ (AC) $\left.{ }_{8} \mathrm{YG}\right)$ ISSR primers amplified. The universal SSR markers rbcL (5'-

AACACCAGCTTTRAATCCAA-3') and MatK (5'-

GGGTTGCTAACTCAATGGTAGAG-3') primers [22] were used to validate the quality of extracted wood DNA. In this study, basically particular universal SSR primers which were used to carry out research in barcoding of timbers, which would be useful in illegal logging and tracing the timber origin. DNA amplification was carried out in $13 \mu \mathrm{L}$ reaction volume containing genomic DNA $1.5 \mu \mathrm{L}$ (30 ng/ $\mu \mathrm{L}$ ), $10 \mathrm{mM} 2 \mu \mathrm{L}$ primers, $1.5 \mu \mathrm{L}$ PCR buffer, $1.5 \mu \mathrm{L}$ dNTPs, $1.5 \mu \mathrm{L}$ $\mathrm{MgCl}_{2}, 0.3 \mu \mathrm{L}(3 \mathrm{U} / \mu \mathrm{L})$ Taq polymerase (Bangalore genie) and $4.2 \mu \mathrm{LRNase}$ freedouble distilled water (Sigma aldrich). Amplification cycle consist of an initial 3 min denaturation at $94^{\circ} \mathrm{C}, 30$ cycles for $30 \mathrm{sec}$ at $50^{\circ} \mathrm{C}, 1 \mathrm{~min} 72^{\circ} \mathrm{C}$ and final extension step for $10 \mathrm{~min}$ at $72^{\circ} \mathrm{C}$. The amplified product loaded with $5 \mu \mathrm{L}$ loading buffer were size fractionated by electrophoresis on a 1.5\% for ISSR and $2.0 \%$ SSR agarose gel with $0.3 \%$ Ethidium bromide and visualized on UV transilluminator to determined the amplified clear bands to validated the DNA quality and suitability for PCR reactions.

\section{Results}

Isolation of DNA from CTAB method and using plant DNA extraction kits were 
unable to extract DNA from wood tissues. Hence we developed a new modified protocol by modifying the CTAB protocol [23] by enhancing the incubation time, $\mathrm{CTAB}$ concentration, high concentration of proteinase and RNase treatment and most important keeping the sample in water to release the resilience of cells by process of osmosis. The ratio of extraction buffer and sample was 500 mg: $5 \mathrm{~mL}$. The additional washing with C: I (24:1) helped to removal of polysaccharides and strong protein contamination.

Table 1 represented the quantity and quality of leaf, sapwood and heartwood tissues with all four protocols, which were used to standardize the protocol 3 to yield high genomic DNA with all selected timber species. For comparative purposes (Figure 2) DNA extraction of leaves, sapwood and heartwood tissues the graph of nanodrop were representing the quantity and qualitative analysis of all three selected species. It was summarized in which shows that the yield of DNA from sapwood from $0.26-0.244 \mu \mathrm{g} / \mu \mathrm{L}$ in heartwood from $0.186-0.166 \mu \mathrm{g} / \mu \mathrm{L}$ and in leaf samples from $1.30-1.511 \mu \mathrm{g} / \mu \mathrm{L}$ according to spectrophotometer measurements with respect to purity from $1.7-1.8$. In general, a higher quantity of DNA could be obtained using modified CTAB protocol (Figure 3 ). The quantity of DNA from Dried leaf samples and from wood samples was $56 \%$ higher than the CTAB and other DNA kit protocol. In Figure 4(a) and Figure 4(b) were showing the DNA bands obtained by protocol 1 i.e., CTAB method and protocol 2,3 i.e., DNA isolation kits which is basically used for industrial purpose and specific for plant genomic DNA isolation. The bands were not clear and the pellet was dark brownish in color with undissolved PCR inhibitors (carbohydrate and proteins) contaminations. Figure 4(c) and Figure 4(d) was presenting the PCR amplification of DNA extracted through protocols 1,2 but in

Table 1. DNA extraction protocols and yield of extracted DNAfrom T. grandis, D. latifolia and L. lanceolata.

\begin{tabular}{|c|c|c|c|c|c|c|c|}
\hline \multicolumn{2}{|c|}{$T \cdot$ grandis } & \multicolumn{2}{|c|}{ Mature dried leaves } & \multicolumn{2}{|c|}{ Sapwood } & \multicolumn{2}{|c|}{ Heartwood } \\
\hline No. & Protocol & $\begin{array}{c}\text { DNA Yield } \\
(\mathrm{ng} / \mu \mathrm{L})\end{array}$ & $\begin{array}{c}\text { DNA purity } \\
(260 / 280)\end{array}$ & $\begin{array}{c}\text { DNA Yield } \\
(\mathrm{ng} / \mu \mathrm{L})\end{array}$ & $\begin{array}{c}\text { DNA purity } \\
(260 / 280)\end{array}$ & $\begin{array}{c}\text { DNA Yield } \\
(\mathrm{ng} / \mu \mathrm{L})\end{array}$ & $\begin{array}{c}\text { DNA purity } \\
(260 / 280)\end{array}$ \\
\hline 1 & P I & 200 & 1.5 & 120.3 & 1.5 & 95.3 & 1.3 \\
\hline 2 & P II & 95.2 & 1.4 & 86.5 & 1.5 & 43.21 & 1.4 \\
\hline 3 & P III & 1394.06 & 1.8 & 244.64 & 1.7 & 166.95 & 1.7 \\
\hline \multicolumn{2}{|c|}{ D. latifolia } & \multicolumn{2}{|c|}{-} & \multicolumn{2}{|c|}{-} & \multicolumn{2}{|c|}{-} \\
\hline 1. & P I & 163.5 & 1.6 & 195.9 & 1.4 & 76.8 & 1.4 \\
\hline 2. & P II & 98.6 & 1.6 & 51.6 & 1.5 & 40.2 & 1.3 \\
\hline 3 & P III & 1494.42 & 1.8 & 262.67 & 1.7 & 186.50 & 1.7 \\
\hline \multicolumn{2}{|c|}{ L. lanceolata } & \multicolumn{2}{|c|}{-} & \multicolumn{2}{|c|}{ - } & \multicolumn{2}{|c|}{-} \\
\hline 1. & P I & 173.7 & 1.3 & 90.2 & 1.5 & 65.1 & 1.3 \\
\hline 2. & P II & 90.3 & 1.6 & 51.6 & 1.4 & 40.2 & 1.3 \\
\hline 3 & P III & 1511.38 & 1.8 & 224.024 & 1.9 & 193.80 & 1.8 \\
\hline
\end{tabular}




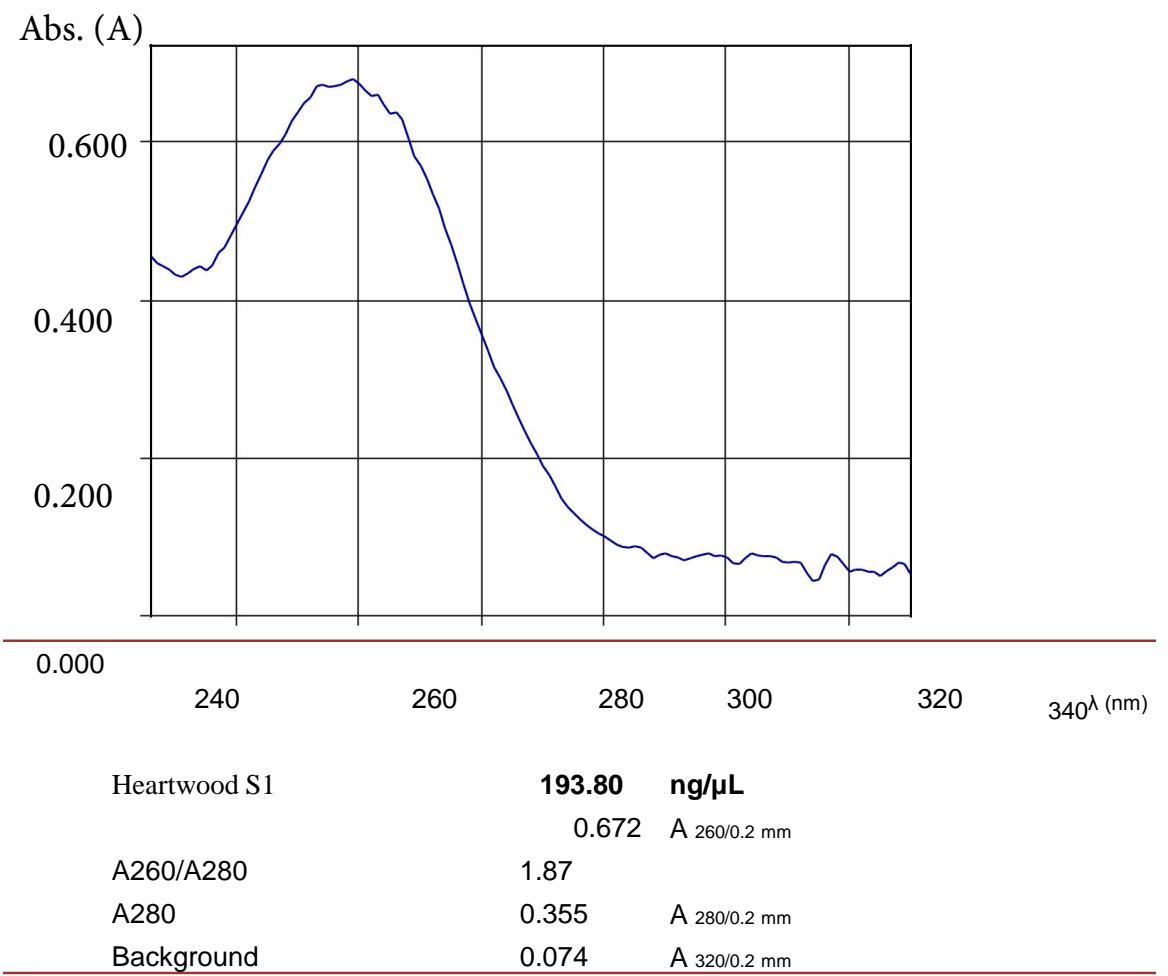

Figure 2. Nanodrop measurement profile of wood genomic DNA extractions from D. latifolia heartwood samples.

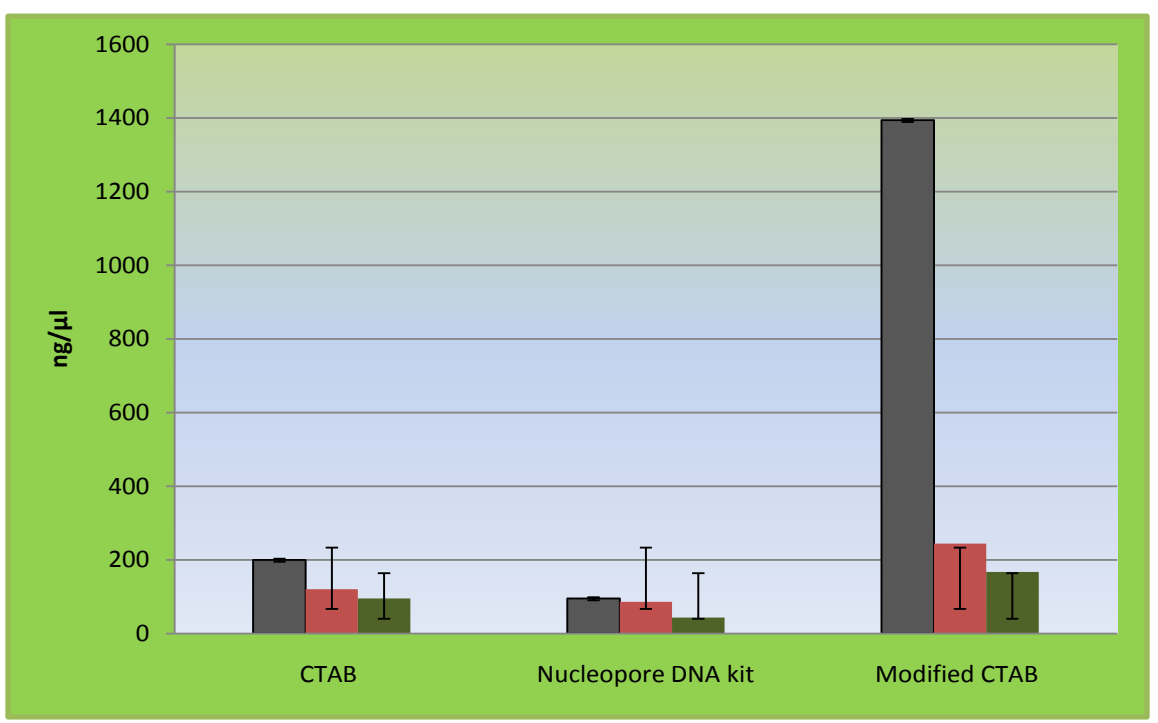

Figure 3. Comparison of the quantity of DNA (ng/mg) extracted from different plant tissues (Dried mature leaf, sapwood and heartwood) using the CTAB, Nucleopore DNA extraction kits, and modified CTAB DNA extraction protocol.

few samples it was some not clear bands. Figure 4(e) was presenting developed method i.e., protocol 3 DNA bands and the same obtained DNA amplification through ISSR primers were in Figure 4(f). DNA quality was always validated by its amplification through PCR with desirable primers. So to conclude the stan- 

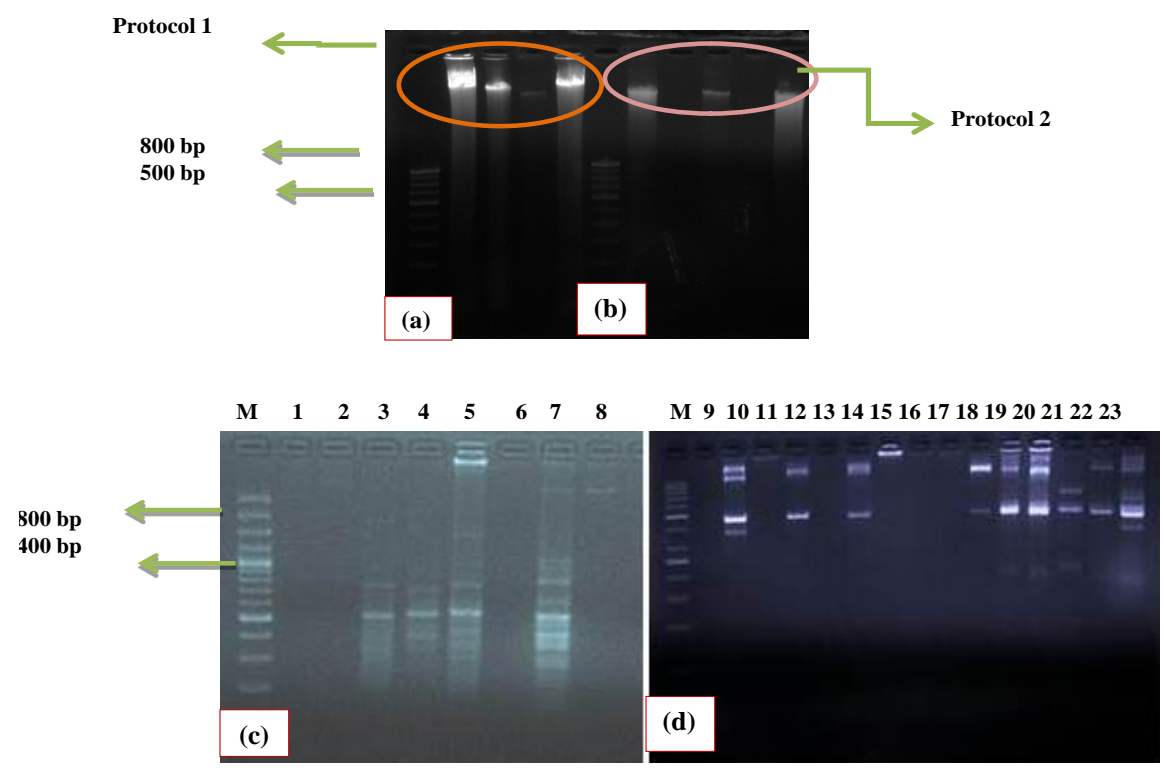

$\begin{array}{lllllllllllllllllllllll}M & 1 & 2 & 3 & 4 & 5 & 6 & 7 & 8 & 9 & 10 & M & 1 & 2 & 3 & 4 & 5 & 6 & 7 & 8 & 9 & 10 & 11\end{array}$

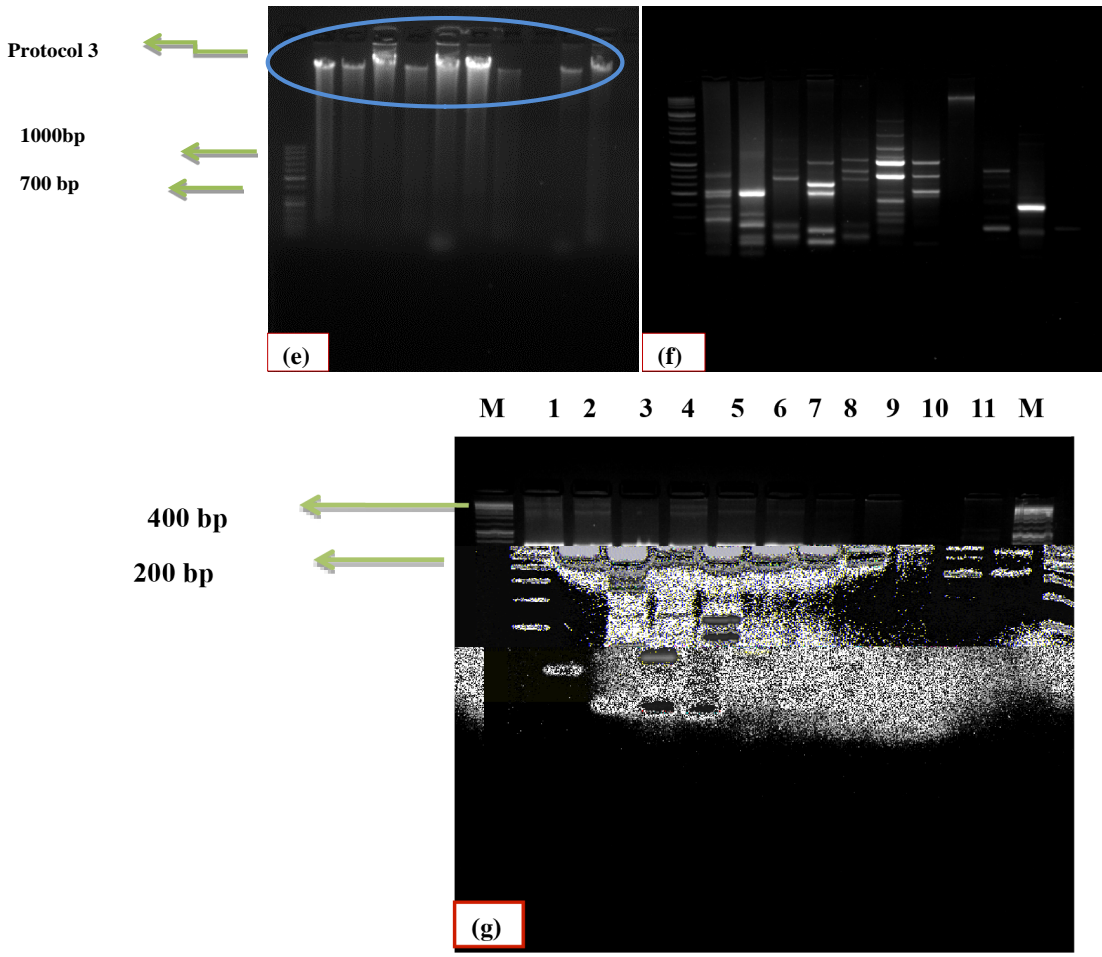

Figure 4. (a) Gel image of the genomic wood DNA of studied core samples isolated by Protocol 1; (b) Gel image of the genomic wood DNA of studied core samples isolated by Protocol 2,3; (c) ISSR bands obtained from DNA extracted from protocol 1 with UBC834M. Ladder 100 bp. (Bangalore genie); (d) ISSR bands obtained from DNA extracted from protocol 2,3 with UBC834M. Ladder 100 bp (Bangalore genie); (e) Gel image of the genomic wood DNA of studied core samples isolated by optimized protocol M. Ladder 100 bp (Bangalore genie); (f) ISSR bands obtained from DNA extracted from optimized protocol with UBC834M. Ladder 100 bp (Bangalore genie); (g) SSR primer amplification DNA fragment with RbcL. M. Ladder 50 bp (Bangalore genie) 1) Leaf 2) Sapwood 3) Heartwood ( $T$. grandis), 4) Leaf 5) Sapwood 6) Heartwood (D. latifolia) 7) Leaf 8). Sapwood 9) Heartwood (L. lanceolata) 10) Negative control (DNA dilution 1:10). 
dard protocol validation, the extracted DNA was amplified with universal SSR primers and the result was positively clear bands.

\section{Discussion}

DNA extraction from wood is difficult due to presence of hard tissues with high quantity of cellulose, hemicellulose and polyphenoliclignin compounds. These contents inhibits the DNA isolation and modification in the standardized protocol include svarious conc. CTAB, PVPP, $\beta$-mercaptoethanol, incubation time, RNase treatment and Proteinase treatment.By taking into consideration the important factors such as quantity, quality and suitability for PCR by using ISSR and SSR primers as well as the required time duration to extract DNA, among four methods the modified protocol of CTAB was found best protocol. In order to extract the DNA from wood, key footstep was to loosen the wood cell wall by placing it into water for three days without any fungal contamination. Due to hard nature of wood cell wall and there may be incomplete breakdown of the cell wall to release the cellular constituents, the penetration of water in the wood cells plays important role in sample preparation of DNA extraction. Result of the gel electrophoresis and spectrophotometer showed that the DNA purity was enhanced as well as polysaccharides and protein contaminations were removed by applying the modified protocol. The absence of RNA, polysaccharides and the amplification of desired primers (ISSR, SSR) with clear bands on $1.5 \%$ agarose gel were noticeable of a superior feature of DNA.

\section{Conclusion}

The present analysis clearly established the need for different tree species of appropriate DNA isolation methods for timber species. A single method may not be appropriate for extraction of DNA with good quantity and purity from all species but this method could be executed as standard method for isolation of wood DNA from D. latifolia, L. lanceolata and T. grandisor similar perennial timber species containing rich polysaccharides and defined here is hasty, uncertain and steady permitting the handling of large number of trials with easy routine. Previous studies [24] relying on relatively fresh samples but by using this developed protocol we could able to isolate pure DNA from mature dried wood samples of timbers or perennial tree species. Through Figure 4 the final validation of qualitative DNA was proved that this protocol would be useful for each species of wood and mature dried or even disintegrating leaves of timber species. The isolated DNA as a result of using standardized protocol of various wood samples (fresh, dried, old and mature cores) was tested in PCR amplification for ISSR and ISSR profiling with selected primers to validate the protocol.

\section{Acknowledgements}

Authors are thankful to the Director, Group Coordinator Research, Head-Tree Improvement and Genetics Division, Institute of Wood Science and Technology 
and The Additional Principal Chief Conservator of Forest (research) the Karnataka Forest Department for financial support.

\section{References}

[1] SCBD. COP-10 (2010) Decision X/2. Secretariat of the Convention on Biological Diversity.

[2] Amaral, W., Kjaer, E.D., Yanchuk, A. and Graudal, L. (2004) Research Needs. In: FAO, FLD, IPGRI, Eds., Forest Genetic Resources: Conservation and Management, International Plant Genetic Resources Institute, Rome, 37-48.

[3] Phillips, O.L., Vasquez, M.R., Nunez, V.P., Lorenzo, M.A., Chuspe, Z.M.E. and Galiano, S.W. (2003) Efficient Plot-Based Floristic Assessment of Tropical Forests. Journal of Tropical Ecology, 19, 629-645. https://doi.org/10.1017/S0266467403006035

[4] Webb, C.O., Slik, J.W.F. and Triono, T. (2010) Biodiversity Inventory and Informatics in Southeast Asia. Biodivers Conservtion, 19, 955-972.

https://doi.org/10.1007/s10531-010-9817-x

[5] EIA/Telapak (2001) Timber Trafficking: Illegal Logging in Indonesia, Southeast Asia and International Consumption of Illegally Sourced Timber. Bogor, Telapak and EIA.

[6] Deguilloux, M.F., Pemonge, M.H. and Petit, R.J. (2002) Novel Perspectives in Wood Certification and Forensics: Dry Wood as a Source of DNA. Proceedings of the Royal Society of London, 269, 1039-1046. https://doi.org/10.1098/rspb.2002.1982

[7] Finkeldey, R., Rachmayanti, Y., Nuroniah, H., Nguyen, N.P., Cao, C. and Gailing, O. (2007) Identification of the Timber Origin of Tropical Species by Molecular Genetic Markers-The Case of Dipterocarps. Proceedings of the International Workshop “Fingerprinting Methods for the Identification of Timber Origin", 20-27.

[8] Asif, A.J. and Cannon, C.H. (2005) DNA Extraction from Processed Wood: A Case Study for the Identification of an Endangered Timber Species (Gonystylus bancanus). Plant Molecular Biology Reporter, 23, 180-187. https://doi.org/10.1007/BF02772709

[9] Cannon, C.H. and Manos, P.S. (2003) Phylogeography of the Southeast Asian Stone Oaks (Lithocarpus). Journal of Biogeography, 30, 211-226. https://doi.org/10.1046/j.1365-2699.2003.00829.x

[10] Kajita, T., Kamiya, K., Nakamura, K., Tachida, H., Wickneswari, R., Tsumura, Y., Yoshimaru, H. and Yamazaki, T. (1998) Molecular Phylogeny of Dipterocarpaceae in Southeast Asia Based on Nucleotide Sequences of matK-trnL Intron, and trnL-trnF Intergenic Spacer Region in Chloroplast DNA. Molecular Phylogenetics and Evolution, 10, 202-209. https://doi.org/10.1006/mpev.1998.0516

[11] Sascha, L., Sperisen, C., Deguilloux, M.F., Petit, R.J., Kissling, R., Spencer, M., Beaulieu, J.L.D., Taberlet, P., Gielly, L. and Ziegenhagen, B. (2006) Authenticated DNA from Ancient Wood Remains. Annals of Botany, 98, 1107-1111. https://doi.org/10.1093/aob/mcl188

[12] Swetha, V.P., Parvathy, V.A., Sheeja, T.E. and Sasikumar, B. (2014) Isolation and Amplification of Genomic DNA from Bark of Cinnamomum spp. Turkish Journal of Biology, 38, 151-155. https://doi.org/10.3906/biy-1308-5

[13] Verbylaite, R., Beisys, P., Rimas, V. and Kuusiene, S. (2010) Comparison of Ten DNA Extraction Protocols from Wood of Europian Aspen (Populus tremula L.). Baltic Forestry, 16, 32-42. 
[14] Rachmayanti, Y., Leinemann, L., Gailing, O. and Finkeldey, R. (2006) Extraction, Amplification and Characterization of Wood DNA from Dipterocarpaceae. Plant Molecular Biology Reporter, 24, 45-55. https://doi.org/10.1007/BF02914045

[15] Deguilloux, M.F., Pemonge, M.H. and Petit, R.J. (2003) Checking the Geographical Origin of Oak Wood Molecular and Statistical Tools. J. Mol Eco, 12, 1629-1636. https://doi.org/10.1046/j.1365-294X.2003.01836.x

[16] Murray, M.G. and Thompson, W.F. (1980) Rapid Isolation of High Molecular Weight Plant DNA. Nucleic Acids Research, 8, 4321-4325. https://doi.org/10.1093/nar/8.19.4321

[17] Rawat, S., Joshi, G., Annapurna, D., Arunkumar, A. and Karaba, N. (2016) Standardization of DNA Extraction Method from Mature Dried Leaves and ISSR-PCR Conditions for Melia dubia Cav.-A Fast Growing Multipurpose Tree Species. American Journal of Plant Sciences, 7, 437-445. https://doi.org/10.4236/ajps.2016.73037

[18] Tibbits, J.F.G., McManus, L.J., Spokevicius, A.V. and Bossinger, G. (2006) A Rapid Method for Tissue Collection and High-Throughput Isolation of Genomic DNA from Mature Trees. Plant Molecular Biology Reporter, 1, 81-91. https://doi.org/10.1007/BF02914048

[19] Sambrook, J., Maccallum, P. and Russell, D. (2001) Molecular Cloning: A Laboratory Manual. 3rd Edition, Cold Spring Harbor Press, Cold Spring Harbor, 2344 p.

[20] Alhasnawi, A.N., Kadhimi, A.A., Isahak, A., Ashraf, M.F., Doni, F., Mohammad, A., Yusoff, W.M.W. and Zain, C.R.C.M. (2015) Application of Inter Simple Sequence Repeat (ISSR) for Detecting Genetic Analysis in Rice (Oryza sativa L.). Journal of Pure and Applied Microbiology, 9, 1091-1101.

[21] Xiaoshu, T., Zhao, G. and Ping, L. (2011) Wood Identification with PCR Targeting Noncoding Chloroplast DNA. Plant Molecular Biology, 77, 609-617. https://doi.org/10.1007/s11103-011-9837-2

[22] Dev, S.A., Muralidharan, E.M., Sujanapal, P. and Balasundaran, M. (2013) Identification of Market Adulterants in East Indian Sandalwood using DNA Barcoding. Annals of Sciences, 13595, 13-34.

[23] He, D., Liu, Y., Cai, M., Pan, H.T., Zhang, Q.X., Wang, X.Y. and Wang, X.J. (2012) Genetic Diversity of Lagerstroemia (Lythraceae) Species Assessed by Simple Sequence Repeat Markers. Genetics and Molecular Research, 3, 3522-3533. https://doi.org/10.4238/2012.September.26.9

[24] Doyle, J.J. and Doyle, J.L. (1987) A Rapid DNA Isolation Procedure for Small Quantities of Fresh Leaf Tissue. Phytochemical Bulletin, 19, 11-15. 